\title{
Review of International Studies
}

Volume 9 Number 2 April 1983

\section{Contents}

Notes on contributors

In the interest of peace and progress:

Eduard Bernstein's socialist foreign policy

R. A. FLETCHER

Ireland and the United Nations Peacekeeping Force in Cyprus NORMAN MACQUEEN

The United Nations Convention on Prohibitions or Restrictions on the Use of Certain Conventional Weapons, 1981

MALCOLM SHAW

International relations and the promptings of history

CHRISTOPHER THORNE

Review articles

Rosenau's contribution

SteVe SMith

The threat of wrong

ROBIN ATTFIELD 